which was formed in 1921, early commenced a systematic investigation of each section of the laundry process. It instituted methods of measuring colour and observing the efficiency of cleansing on washed articles. Research work now in progress includes studies of the fundamentals of detergency, for example, an investigation of the physical properties of soap and alkaline solutions as well as those of the new detergents known as sulphonated fatty alcohols. Work is also proceeding upon engineering problems which are encountered in laundry machinery. The examination of plant, products and materials, of new and laundered fabrics, is a part of the routine work of the laboratories. In addition, an analytical department undertakes the analysis of products used by the launderers. The information gained is published in the form of reports to members, and a bulletin is issued quarterly in order to inform members of the work in progress, etc. The Association has published three books : "Control of Laundry Operations", "Chemistry of Laundry Materials" and, recently, "Technology of Washing".

\section{Ancient Egyptian Sculpture}

Mr. C. S. Gulbenkian's loan to the British Museum (Bloomsbury) of fourteen pieces of ancient Egyptian sculpture from his collection, for a period of eighteen months, which is now on view in the entrance hall, not only illustrates Egyptian art for a period of 2,000 years from the Middle Kingdom to Ptolemaic times, but it also serves to bring out in a marked degree certain characteristics in which the masterpieces of that art stand out, as against the products of the classical period, and in which it is, in fact, closely akin to the aims of certain schools of modern art. Egyptian art, and more especially Egyptian sculpture, when freed from the conventions imposed by the necessities of formal presentation for State or official purposes, showed a remarkable, and indeed an exceptional, ability to express character and individuality in portraiture. While this is generally admitted in the obvious instance of the Tell el-Amarna school under the influence of Akhnaton, which usually, though not invariably, emphasizes and idealizes a defect, it would seem, in preference to strength, it is equally true of the more robust tradition, which can be traced so far back as the Fourth Dynasty and produced, for example, such well-known specimens as the statuette of Khufu and the effigy of the "Sheikh ed-Beled". That this tradition persisted through a prolonged period can be seen in some of the later exhibits in the British Museum loan collection, such as, for example, the remarkable head of a man in green schist of the sixth century B.C., though possibly many may consider the gem of the collection to be the head in obsidian attributed as a portrait of Amenemhat III to the Twelfth Dynasty, in which the characterization is no less remarkable than the technical skill, which could subdue so refractory a material to its purpose. Another exhibit, in bronze, though of a different genre, attracts attention, and charms by its unusual subject-a cat with two kittens playing.

\section{Sir Robert Hadfield's Gift to Harvard}

IN a supplement to the Engineer of November 20, there were reproduced photographs of four very striking water-colour drawings depicting war-time work in three departments of Messrs. Hadfields Itd., of Sheffield. The artist, Mr. Herbert $J$. Finn, in these drawings, has succeeded in conveying in a remarkable manner the sense of intense activity and vibrant energy of the giant furnaces and myriads of whirling belts of an engineering shop, which may come to be regarded as characteristic of this machine age. Equally vivid, but of totally different character, is Mr. Finn's water colour "Oxford from the Sheldonian Theatre", a pictorial representation of Oxford's spires and domes-a vista breathing the peace and quietude of medieval England. Sir Robert Hadfield has acquired this picture and has presented it to Harvard University in connexion with the occasion of its tercentenary celebrations. Harvard's leading metalIurgist, Prof. Albert Sauveur, himself an old friend of Sir Robert, is well known in British engineering circles, for he was the recipient in 1924 of the Bessemer Gold Medal of the Iron and Steel Institute; on the other hand, Sir Robert is probably equally well known on the west of the Atlantic, for he is a foreign associate of the National Academy of Sciences, he received the John Fritz Gold Medal of the United Engineering Societies of the United States in 1921 and the Elliott-Cresson Gold Medal of the Franklin Institute in 1901. Sir Robert's gift is not only a mark of his own respect and admiration for a great centre of learning in the United States, but also a further link between the universities of Great Britain and the New World, helping to hold them together in the ever-intensifying quest for knowledge.

\section{The Parliamentary Science Committee}

The Council of the British Association resolved, at its meeting on Friday last, that the Association should become a constituent member of the Parliamentary Science Committee, and appointed as its representative Prof. Allan Ferguson, one of the general secretaries of the Association. The arrangement made is subject to revision after three years. The announcement will afford particular pleasure to the members of the British Science Guild, which has now been incorporated with the British Association. The Guild and the Association of Scientific Workers were the parent bodies of the Parliamentary Science Committee, which came into being in October 1933, almost immediately after the presidential address of Sir Frederick Gowland Hopkins at the Leicaster meeting of the British Association.

\section{Research Co-ordination Group}

Ax a meeting on December 2 at River Court, Hammersmith, London, W.6 of the Research Coordination Group (see NATURE of February 22, p. 31I, and May 30, p. 898) a number of problems dealing mainly with (1) rise in the standard of living and (2) security, were suggested for the attention of scientific investigators. Among these were: the standardization and extension of statistical information, both as 
regards production and consumption; nutritional needs and national fitness; population problems and genetics questions; scientific agriculture, afforestation, land reclamation; regional distribution of industry; hydro-electric power, new industrial developments (light metals, carbide and acetylene, plastics, cellulose, synthetic fats); aircraft and poison gas defence; psychology and war; educational use of cinema; vocational outlet for trained workers; and several others. These are to be grouped around the various sciences to which they are related. The chairman (Sir Richard Gregory) referring to the fact that many of these problems have been discussed at recent meetings of the British Association, suggested that the closest co-operation be maintained with the Association, and it was agreed that, if possible, suggestions be made to recorders of suitable sections for the inclusion of such papers in the programme of the next meeting at Nottingham. Material on the above or other suitable topics should be sent to the Honorary Secretary, Research Co-ordination Committee, Hazlitt House, Southampton Buildings, W.C.2 (Telephone, Holborn 1713).

\section{Relativity and the Quantum Theory}

IN a lecture given before the Newcastle-upon-Tyne Astronomical Society on Novernber 5, Prof. R. A. Sampson discussed "The Spectroscope in the Observatory". Remarking that the spectrum, along with Wilson's cloud chamber and photographs of diffraction patterns due to electrons, furnishes visible records of things that are too small to see, Prof. Sampson pointed out that Dirac holds it is quite impossible to make a rational theory of these things without reconstructing our ideas of the nature of matter altogether. This has led to the two great theories of modern times, namely, relativity and the quantum theory. They are not yet fully reconciled. In his opinion, there are considerable philosophical diffeulties in holding either. Relativity, on its merits, may seem a probable theory, but it cannot do its feats without making time an equal co-ordinate with the familiar three of space. Now we cannot think time away, without sacrificing the possibility of expressing ourselves intelligibly to others, and living in a world where history and cause and effect have no meaning. Nor does it upset our own affairs alone; we see the grass grow in summer and die away in winter. That must be an illusion. It seems to Prof. Sampson a simpler hypothesis to suppose that the intellect is limited. The quantum theory, which is obviously on the right lines, makes in small matters an enormous logical difference, and gives a new meaning to the question "Will the sun rise tomorrow ?"-for example, when we are dead, or last century, before we were born. We must confess that we have no means of verifying whether it does or not. It seems that both these theories spell the exhaustion of the constructs of the intellect, of which a necessary part is the four elements of space-time, which must be exhausted sooner or later. Leaving these philosophical questions, Prof. Sampson gave a description of the ordinary theory of stellar sequences, etc., including the Russell diagram of the relation of luminosity to spectral class, and white dwarfs.

\section{Supervision of the Nation's Food Supply}

IN the fifteenth Benjamin Ward Richardson Lecture which was delivered on November 10 before the Royal Sanitary Institute, Dr. Gerald Leighton, late Medical Officer of the Department of Health for Scotland, stated that from the public health point of view three conditions are required for the proper supervision of the nation's food supply. In the first place, there must be a concentration and collection at certain centres of large quantities of the food material, so that there may be adequate inspection. Although the necessity of this condition was recognized more than forty years ago by the United States Department of Agriculture, which established a wellregulated system of slaughter houses, Great Britain has been very slow in adopting the system of public abattoirs, the need of which was so strongly urged by Benjamin Ward Richardson himself. The second condition necessary for effective supervision is the supply of a sufficient number of highly trained inspectors. Great progress has been made in this respect during the last twenty years, training for students as meat inspectors being provided by veterinary colleges, some universities and other educational bodies. Lastly, a uniformity of system and practice is essential. The inspectors should be trained to work on a uniform system and to a uniform standard instead of, as in the old days, each inspector being a law to himself. Dr. Leighton then dwelt on the desirability of securing and adopting the most rapid, skilled and humane methods of slaughtering all kinds of animals for human food, a topic which formed part of the life work of Richardson. In conclusion, he expressed the view that in the progress of the supervision of a nation's food, the introduction. of legal standards, as in most European countries, America and various parts of the Empire, for the majority of foods is the most important step for future development.

\section{The London Telephone Trunk Exchange}

Is a paper read on November 13 to the Students' Section of the Institution of Electrical Engineers, Mr. H. M. Wells discusses the effects of the rapid increase of the telephone service in Great Britain on the methods of working. The country is divided up into zone areas and subdivided into group areas. Major trunk lines connect main zone exchanges with London and with one another. They are so designed that a minimum of duplicate plant is necessary. By the use of thermionic amplifiers, the volume of speech fed into a line is made equal to the volume received at the far end. When things are properly adjusted, there is thus no loss of sound. One result is that the speech on the London-Moscow circuit is as good as that on a local London call. The insula. tion materials of the cables used are paper and 'air-space'. The 'air-space' is filled with carbon dioxide which possesses desiccating qualities and 